\title{
EFEKTY I MOŻLIWOŚCI TERMOMODERNIZACJI BRYŁY ZABYTKOWEGO, MUROWANEGO KOŚCIOŁA
}

\begin{abstract}
W artykule przedstawiono, w jakim stopniu wykonanie dozwolonych przez konserwatora prac związanych z ociepleniem bryły zabytkowego, murowanego kościoła spowoduje zmniejszenie rocznego zużycia energii na cele grzewcze oraz ograniczy występowania w kościele różnych, niekorzystnych zjawisk związanych z przepływem ciepła i wentylacją. Analizowano również, o ile po termomodernizacji może zmniejszyć się zużycie paliwa tj. gazu lub węgla na cele grzewcze i tym samym emisja $\mathrm{CO}_{2}$ do atmosfery. Porównano efekty takiej termomodernizacji, przy stałym i okresowym sposobie ogrzewania kościoła oraz gdyby był on zlokalizowany w różnych miastach Polski. Do analizy przyjęto bryłę zabytkowego kościoła znajdującego się w gminie Zarszyn.
\end{abstract}

Słowa kluczowe: energia użytkowa, ogrzewanie, szklenie osłonowe, emisja $\mathrm{CO}_{2}$

\section{Wprowadzenie}

W związku ze wzrastającymi cenami nośników energii, również proboszczowie zabytkowych kościołów starają się o pozyskanie środków i wykonanie prac mających na celu zmniejszenie kosztów ogrzewania kościoła. W ostatnich latach w wielu kościołach w pierwszej kolejności dokonano modernizacji źródeł ciepła, wymieniając min. stare kotły na nowe, czy też zastępując ogrzewanie węglem na ogrzewanie gazem. W dalszej kolejności brane jest pod uwagę wykonanie prac, które nie tylko polegałyby na pracach odtworzeniowych, ale również przyczyniłyby się do poprawy warunków cieplno-wilgotnościowych panujących w kościele i mających decydujący wpływ na znajdujące się w kościele zabytkowe wyposażenie. Często ograniczony budżet parafii zmusza do rozłożenia takich prac w czasie i wyboru w pierwszej kolejności tych, które przyniosą najlepsze efekty.

Ze względu na możliwości uzyskania dofinansowania ze środków unijnych, wykonano wiele projektów termomodernizacji budynków zabytkowych i znajdu-

\footnotetext{
${ }^{1}$ Dorota Machowska, Politechnika Krakowska, Wydział Architektury, Instytut Projektowania Budowlanego, ul. Podchorążych 1, 30-084 Kraków; tel. 126282459; machowska@pk.edu.pl
} 
jących się w nich systemów grzewczych, co min. zostało przedstawione w publikacjach [1] i [2]. W niniejszym artykule analizowano, w jakim stopniu wykonanie dozwolonych przez konserwatora prac związanych wyłącznie z ociepleniem bryły zabytkowego, murowanego kościoła spowoduje zmniejszenie zużycia energii na cele grzewcze i tym samym zużycia paliwa tj. gazu lub węgla oraz obniży emisję $\mathrm{CO}_{2}$ do atmosfery. Porównano, jakie byłyby efekty termomodernizacji, gdyby ta sama bryła kościoła była zlokalizowany w różnych rejonach Polski. Porównano efekty dla ciągłego i okresowego trybu pracy ogrzewania.

\section{Analiza możliwych do przeprowadzenia prac związanych z termomodernizacją bryły zabytkowego, murowanego kościoła}

Decydujące zdanie, co do możliwego zakresu prac związanych z ociepleniem budynku ma konserwator zabytków, którego opinia jest wymagana przy składaniu projektu do pozwolenia na budowę. Przy zabytkowym charakterze kościoła zazwyczaj nie jest możliwe ocieplenie ścian od zewnątrz, ze względu na różne ozdobne detale znajdujące się na elewacji. Ocieplenie ścian od środka z zastosowaniem specjalnych płyt, zazwyczaj też nie jest możliwe, ze względu na znajdujące się na ścianach malowidła, jak również wysoki koszt takich płyt. Trudne do przeprowadzenia jest również ocieplenie podłogi. Zazwyczaj więc jedynymi częściami bryły zabytkowego kościoła, w które można w pewnym stopniu ingerować jest sklepienie i okna.

Sposób ocieplenia sklepienia zależeć będzie od jego budowy. Płaskie i mniej strome odcinki sklepień można ocieplić np. płytami z wełny mineralnej o grubości np. $25 \mathrm{~cm}$, a tzw. ,pachy” w sklepieniu palmowym można zasypać lekkim granulatem termoizolacyjnym, zagęszczanym warstwowo. Oprócz ograniczenia strat ciepła, ocieplenie sklepienia wyeliminuje niekorzystne zjawisko związane z przepływem ciepłego (ogrzanego) powietrza wzdłuż zimnych powierzchni, którego efektem jest czernienie tej powierzchni. Zaczernienia te powstają w pierwszej kolejności w miejscach, gdzie powierzchnie wewnętrzne mają najniższe temperatury. Poza tym przy niezaizolowanym sklepieniu temperatura jego powierzchni będzie niższa, niż w przypadku sklepienia zaizolowanego i tym samym dopuszczalna wilgotność względna powietrza w kościele, przy której nie będzie kondensacji powierzchniowej będzie również niższa.

Termomodernizacja okien polegać może na zastosowaniu od zewnętrznej strony okna szklenia osłonowego. Jednak w pierwszej kolejności wskazane jest przeprowadzenie przez specjalistę demontażu i konserwacji witraży. Zabiegi konserwacji szkła witrażowego polegają na oczyszczeniu, uzupełnieniu ubytków malarskich, uzupełnieniu brakujących przeszkleń i klejeniu pękniętych szybek.

Pola witrażowe następnie obejmuje się dodatkową ramką miedzianą i montuje powtórnie z wytworzeniem szczeliny wentylacyjnej pomiędzy dodawanym no- 
wym zestawem szklenia osłonowego i konserwowanym witrażem. Szklenie osłonowe może stanowić np. zestaw hermetyczny 4/8/4 mm. U dołu okna należy zastosować metalową rynnę na skropliny.

Zaizolowanie okien będzie skutkować zmniejszeniem infiltracji powietrza. Jednak uszczelnienie kościoła, w celu zwiększenia efektywności ogrzewania jest działaniem pozostającym w sprzeczności z potrzebą stałego przewietrzania wnętrza i usuwaniu pary wodnej oddawanej przez ludzi, zwłaszcza, że kościoły te często były projektowane na mniejszą ilość osób, niż ta która wynika z obecnego ich użytkowania. Przewietrzanie zabytkowego kościoła zaprojektowane było w ten sposób, że napływające przez nieszczelności okien i drzwi powietrze wylatywało przez otwory o średnicy ok. 0,2 m znajdujące się w sklepieniu nad nawą i prezbiterium. Na rysunku 1 pokazano wnętrze kościoła w Zarszynie, a na rysunku 2 widoczne otwory wentylacyjne w sklepieniu kościoła (rys. 3-4). Otwory te, w zależności od temperatury powietrza na zewnątrz, miały być pozostawione otwarte lub zamykane specjalnymi bloczkami. Zdarza się, że podczas remontu lub termomodernizacji kościoła otwory te są likwidowane i zatykane, aby zmniejszyć straty ciepła. Jest to błędne postępowanie, gdyż pogarsza naturalną wentylację kościoła, która gwarantuje, że cała kubatura kościoła zostanie przewietrzona i nie będzie miało miejsce zaleganie ciepłych mas powietrza pod sklepieniem. Przepływ powietrza przez 4 takie otwory w ciągu godziny, przy temperaturze zewnętrznej ok. $0^{\circ} \mathrm{C}$ może wynosić ok. $500 \mathrm{~m}^{3}$. Zatem otwory te powinno się zachować i najlepiej zabezpieczyć specjalnymi kominkami.

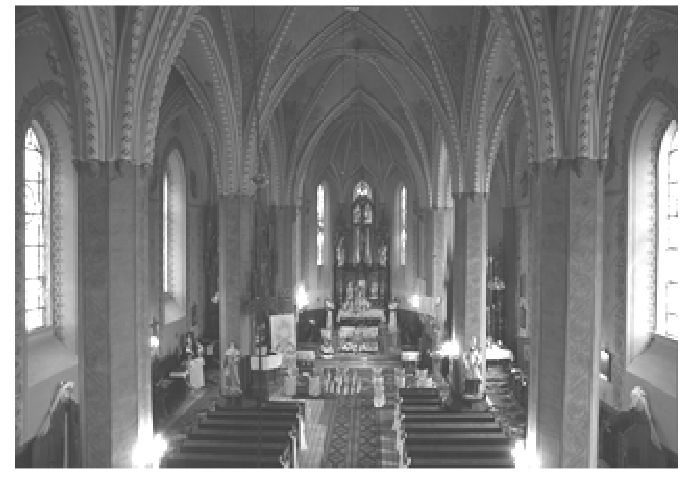

Rys. 1. Wnętrze kościoła w Zarszynie

Fig. 1. Interior of the church in Zarszyn

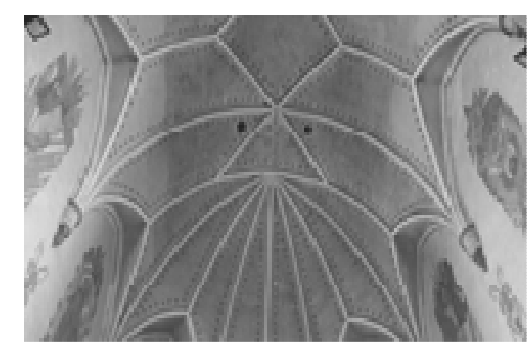

Rys. 2. Sklepienie kościoła $\mathrm{z}$ otworami wentylacyjnymi

Fig. 2. The vaulted ceiling with air holes 


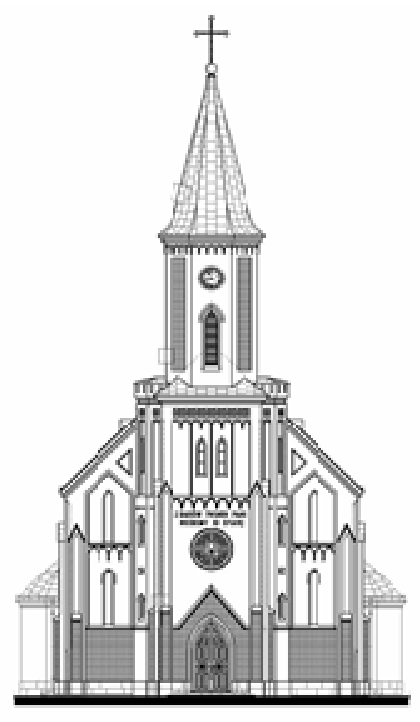

Rys. 3. Elewacja frontowa kościoła w Zarszynie

Fig. 3. The front facade of the church in Zarszyn

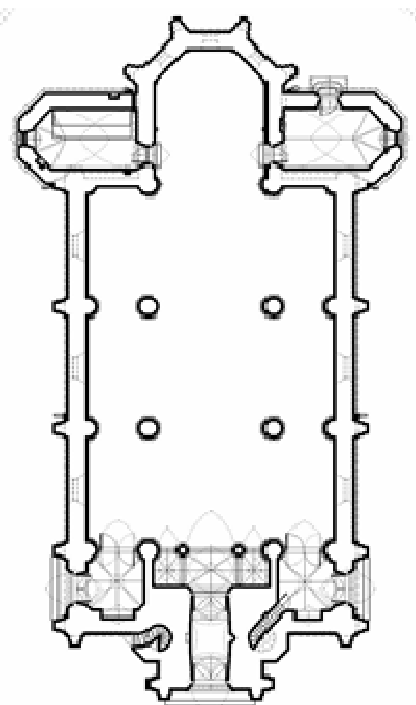

Rys. 4. Rzut kościoła w Zarszynie

Fig. 4. Graphical projection of the church in Zarszyn

Bardzo ważnymi pracami w zakresie termomodernizacji zabytkowego kościoła, oprócz prac związanych z ociepleniem przegród, jest często wykonanie drenażu opaskowego oraz izolacji pionowej i poziomej części fundamentowej kościoła, ponieważ wilgoć nie tylko powoduje destrukcję tynku i muru ale również jest przejmowana przez powietrze $\mathrm{w}$ kościele. Zablokowanie tego procesu często znacznie redukuje wilgotność powietrza w budynku kościoła.

\section{Założenia do obliczeń}

Do analizy efektów energetycznych termomodernizacji przyjęto bryłę zabytkowego kościoła znajdującego się w gminie Zarszyn, powiat Sanok. Kościół ten $\mathrm{w}$ formie neogotyckiej, murowanej został wzniesiony w roku 1872, w miejscu starego, rozebranego kościoła. W czasie II wojny światowej kościół został częściowo zniszczony i dopiero w latach 50-tych ubiegłego wieku zakończono jego odbudowę [3]. Powierzchnia zabudowy kościoła wynosi ok. $680 \mathrm{~m}^{2}$, powierzchnia użytkowa parteru ok. $482 \mathrm{~m}^{2}$, a całkowita kubatura obiektu ok. $11000 \mathrm{~m}^{3}$. Kubatura nawy i prezbiterium wynosi ok. $4400 \mathrm{~m}^{3}$. Na rysunku 3 pokazano widok elewacji frontowej kościoła, a na rysunku 4 jego rzut. Ściany zewnętrzne i wewnętrzne wykonane są z cegły ceramicznej pełnej. Sklepienia nad nawą główną, nawami bocznymi oraz prezbiterium wykonane są również z cegły. Dach budynku o drewnianej konstrukcji pokryty jest blachą. W oknach za- 
montowane są witraże. W kościele wykonano już modernizację ogrzewania i w zakrystii kościoła jest zamontowany nowy kocioł opalanym gazem. Kościół jest ogrzewany rurkami z wodą grzejną rozprowadzonymi między ławkami.

Grubość ścian zewnętrznych kościoła jest różna i wynosi od 0,93 m do $1,81 \mathrm{~m}$, a grubość sklepień od $0,15 \mathrm{~m}$ do $0,26 \mathrm{~m}$. Dla materiałów przyjęto współczynniki przewodzenia ciepła wg obowiązujących norm. Obliczone współczynniki przenikania ciepła dla ścian zewnętrznych wynoszą od $\mathrm{U}=0,36 \mathrm{~W} /\left(\mathrm{m}^{2} \mathrm{~K}\right)$ do $\mathrm{U}=0,72 \mathrm{~W} /\left(\mathrm{m}^{2} \cdot \mathrm{K}\right)$, dla sklepień od $\mathrm{U}=2,2 \mathrm{~W} /\left(\mathrm{m}^{2} \cdot \mathrm{K}\right)$ do $\mathrm{U}=3,2 \mathrm{~W} /\left(\mathrm{m}^{2} \cdot \mathrm{K}\right)$, a dla okien $\mathrm{z}$ witrażami $\mathrm{U}=5,7 \mathrm{~W} /\left(\mathrm{m}^{2} \mathrm{~K}\right)$. Do obliczeń przyjęto ocieplenie sklepienia wełną mineralną o grubości $25 \mathrm{~cm}$, zamontowanie dodatkowego szklenia osłonowego, jednokrotną wymianę powietrza na godzinę w kościele. Zgodnie z [4], uwzględniając sprawność kotła $\eta=0,86$, regulacji $\eta=0,85$ i transportu ciepła $\eta=0,9$, przyjęto sprawność systemu ogrzewania na poziomie $\eta_{H}=0,66$.

W obliczeniach nie uwzględniono ocieplenia podłogi, co w niektórych kościołach jest dopuszczalne, dlatego, że przy liczeniu strat ciepła i uwzględnieniu ekwiwalentnej wartości współczynnika przenikania ciepła U dla podłogi, różnica między wartościami np. $\mathrm{Q}_{\mathrm{H}} \mathrm{w}$ kościele $\mathrm{z}$ ocieploną i nieocieploną podłogą była na poziomie kilku procent.

\section{Wyniki obliczeń}

W przeprowadzonych zgodnie z [4] obliczeniach, oszacowano następujące wartości:

- $\mathrm{Q}_{\mathrm{H}}$ - roczne zapotrzebowanie na energię użytkową do ogrzewania i wentylacji,

- $\mathrm{Q}_{\mathrm{k}, \mathrm{H}}$ - roczne zapotrzebowanie na energię końcową obliczone na postawie wartości $Q_{\mathrm{H}}, \mathrm{z}$ uwzględnieniem sprawności systemu grzewczego $\eta_{\mathrm{H}}$,

- $\mathrm{Q}_{\mathrm{H}, \mathrm{C}}$ - roczne (częściowe) zapotrzebowanie na energię użytkową do ogrzewania, uwzględniające tylko stratę ciepła przez sklepienie i okna, bez wentylacji

- $\mathrm{Q}_{\mathrm{k}, \mathrm{H}, \mathrm{C}}$ - roczne (częściowe) zapotrzebowanie na energię końcową obliczone na postawie wartości $\mathrm{Q}_{\mathrm{H}, \mathrm{C}} \mathrm{z}$ uwzględnieniem sprawności systemu grzewczego $\eta_{\mathrm{H}}$.

$\mathrm{W}$ tabelach 1 i 2 podano wyniki obliczeń $\mathrm{Q}_{\mathrm{H}}$ oraz $\mathrm{Q}_{\mathrm{k}, \mathrm{H}}$, przy założeniu, że kościół ma ogrzewanie ciągłe do temperatury $8^{\circ} \mathrm{C}$. W tabelach 3 i 4 podano wyniki obliczeń $\mathrm{Q}_{\mathrm{H}, \mathrm{C}}$ oraz $\mathrm{Q}_{\mathrm{k}, \mathrm{H}, \mathrm{C}}$ uwzględniające okresowe ogrzewanie kościoła, również do temperatury $8^{\circ} \mathrm{C}$, ale tylko na czas mszy tj. 2 godziny w dzień powszedni i 6 godzin w niedzielę. W tym przypadku nie wykonano pełnych obliczeń, ponieważ przerywany sposób działania ogrzewania i duże zdolności do magazynowania ciepła przez otaczające mury powodują, że starych kościołów nie powinno się obliczać tak jak inne budynki, ponieważ stan równowagi cieplnej tu nie wystąpi. Dlatego też do wstępnej oceny wielkości zapotrzebowania ciepła korzysta się ze wzoru Krischera i Kasta [5]. Powierzchnie nie akumulujące ciepło, czyli stropy i okna liczy się tak jak w innych budynkach, dlatego tylko straty ciepła przez te przegrody uwzględniono w obliczeniach, a poza tym tylko te straty ulegają zmianie. 
Tabela 1. Wyniki obliczeń energetycznych dla budynku kościoła ze stale działającym ogrzewaniem - kościół przed termomodernizacją

Table 1 . The results of calculation of energy for the church with heating operating continuously the church before thermomodernisation

\begin{tabular}{|c|c|c|c|c|c|c|}
\hline Miasto & $\begin{array}{c}\mathbf{Q H}_{\mathbf{H}} \\
{[\mathbf{k W h} / \mathbf{r o k}]}\end{array}$ & $\begin{array}{c}\mathbf{Q}_{\mathbf{k}, \mathbf{H}} \\
{[\mathbf{k W h} / \mathbf{r o k}]}\end{array}$ & $\begin{array}{c}\text { Zużycie } \\
\mathbf{g a z u} \\
{\left[\mathbf{m}^{3}\right]}\end{array}$ & $\begin{array}{c}\text { Emisja } \\
\mathbf{C O} \\
\mathbf{( g a z}) \\
{[\mathbf{t} / \mathbf{r o k}]}\end{array}$ & $\begin{array}{c}\text { Zużycie } \\
\mathbf{w e ̨ g l a} \\
{[\mathbf{t} / \mathbf{r o k}]}\end{array}$ & $\begin{array}{c}\text { Emisja CO } \\
\text { (węgiel) } \\
{[\mathbf{t} / \mathbf{r o k}]}\end{array}$ \\
\hline Przemyśl & 56887 & 86192 & 9012 & 17,2 & 12,4 & 25,6 \\
\hline Białystok & 59964 & 90854 & 9499 & 18,2 & 13,1 & 27,0 \\
\hline Wrocław & 39028 & 59133 & 6183 & 11,8 & 8,5 & 17,6 \\
\hline Warszawa & 36673 & 55565 & 5809 & 11,1 & 8,0 & 16,5 \\
\hline Szczecin & 25685 & 38917 & 4069 & 7,8 & 5,6 & 11,6 \\
\hline
\end{tabular}

Tabela 2. Wyniki obliczeń energetycznych dla budynku kościoła ze stale działającym ogrzewaniem - kościół po termomodernizacji

Table 2. The results of calculation of energy for the church with heating operating continuously the church before thermomodernisation

\begin{tabular}{|c|c|c|c|c|c|c|}
\hline Miasto & $\begin{array}{c}\mathrm{QH}_{\mathrm{H}} \\
{[\mathrm{kWh} / \mathrm{rok}]}\end{array}$ & $\begin{array}{c}\mathbf{Q}_{\mathbf{k}, \mathrm{H}} \\
{[\mathbf{k W h} / \mathbf{r o k}]}\end{array}$ & $\begin{array}{c}\text { Zużycie } \\
\text { gazu } \\
{\left[\mathrm{m}^{3}\right]}\end{array}$ & $\begin{array}{c}\text { Emisja } \\
\mathrm{CO}_{2} \\
(\mathrm{gaz}) \\
{[\mathrm{t} / \mathrm{rok}]}\end{array}$ & $\begin{array}{c}\text { Zużycie } \\
\text { węgla } \\
\text { [t/rok] }\end{array}$ & $\begin{array}{c}\text { Emisja } \mathrm{CO}_{2} \\
\text { (węgiel) } \\
\text { [t/rok] }\end{array}$ \\
\hline Przemyśl & 33124 & 50188 & 5248 & 10,0 & 7,4 & 15,2 \\
\hline Białystok & 35167 & 53283 & 5571 & 10,7 & 7,8 & 16,1 \\
\hline Wrocław & 21084 & 31945 & 3340 & 6,4 & 4,7 & 9,7 \\
\hline Warszawa & 19820 & 30030 & 3140 & 6,0 & 4,4 & 9,1 \\
\hline Szczecin & 12934 & 19596 & 2049 & 3,9 & 2,9 & 5,9 \\
\hline
\end{tabular}

Tabela 3. Wyniki obliczeń energetycznych dla budynku kościoła z okresowo działającym ogrzewaniem - kościół przed termomodernizacją

Table 3. The results of calculation of energy for the church with heating operating periodically the church before thermomodernisation

\begin{tabular}{|c|c|c|c|c|c|c|}
\hline Miasto & $\begin{array}{c}\mathbf{Q H , C} \\
{[\mathbf{k W h} / \mathbf{r o k}]}\end{array}$ & $\begin{array}{c}\mathbf{Q}_{\mathbf{k}, \mathbf{H}, \mathbf{C}} \\
{[\mathbf{k W h} / \mathbf{r o k}]}\end{array}$ & $\begin{array}{c}\text { Zużycie } \\
\mathbf{g a z u} \\
{\left[\mathbf{m}^{\mathbf{3}}\right]}\end{array}$ & $\begin{array}{c}\text { Emisja } \\
\mathbf{\mathbf { C O } _ { 2 }} \\
\mathbf{( g a z}) \\
{[\mathbf{t} / \mathbf{r o k}]}\end{array}$ & $\begin{array}{c}\text { Zużycie } \\
\mathbf{w e ̨ g l a} \\
{[\mathbf{t} / \mathbf{r o k}]}\end{array}$ & $\begin{array}{c}\text { Emisja CO } \\
(\mathbf{w e ̨ g i e l}) \\
{[\mathbf{t} / \mathbf{r o k}]}\end{array}$ \\
\hline Przemyśl & 5593 & 8474 & 886 & 1,7 & 1,2 & 2,6 \\
\hline Białystok & 5762 & 8730 & 913 & 1,7 & 1,3 & 2,6 \\
\hline Wrocław & 5490 & 8318 & 870 & 1,7 & 1,2 & 2,5 \\
\hline Warszawa & 4454 & 6748 & 706 & 1,3 & 1,0 & 2,0 \\
\hline Szczecin & 3690 & 5591 & 585 & 1,1 & 0,8 & 1,7 \\
\hline
\end{tabular}


W tabelach 1 i 3 podano wyniki obliczeń dla kościoła przed termomodernizacją, a w tabelach 2 i 4 po jej wykonaniu.tj. gdy ocieplone zostało sklepienie nad nawą i prezbiterium oraz zamontowano dodatkowe szklenie osłonowe na okna. Obliczono również jaka byłaby emisja $\mathrm{CO}_{2}$ do atmosfery, gdyby paliwem był gaz, a następnie węgiel.

Tabela 4. Wyniki obliczeń energetycznych dla budynku kościoła z okresowo działającym ogrzewaniem - kościół po termomodernizacji

Table 4. The results of calculation of energy for the church with heating operating periodically the church after thermomodernisation

\begin{tabular}{|c|c|c|c|c|c|c|}
\hline Miasto & $\begin{array}{c}\mathbf{Q H , C} \\
{[\mathbf{k W h} / \mathbf{r o k}]}\end{array}$ & $\begin{array}{c}\mathbf{Q}_{\mathbf{k}, \mathbf{H}, \mathbf{C}} \\
{[\mathbf{k W h} / \mathbf{r o k}]}\end{array}$ & $\begin{array}{c}\text { Zużycie } \\
\mathbf{g a z u} \\
{\left[\mathbf{m}^{\mathbf{3}}\right]}\end{array}$ & $\begin{array}{c}\text { Emisja } \\
\mathbf{\mathbf { C O } _ { 2 }} \\
\mathbf{( g a z}) \\
{[\mathbf{t} / \mathbf{r o k}]}\end{array}$ & $\begin{array}{c}\text { Zużycie } \\
\mathbf{w e ̨ g l a} \\
{[\mathbf{t} / \mathbf{r o k}]}\end{array}$ & $\begin{array}{c}\text { Emisja CO } \\
\text { (węgiel) } \\
{[\mathbf{t} / \mathbf{r o k}]}\end{array}$ \\
\hline Przemyśl & 732 & 1109 & 116 & 0,2 & 0,2 & 0,3 \\
\hline Białystok & 755 & 1144 & 120 & 0,2 & 0,2 & 0,3 \\
\hline Wrocław & 719 & 1089 & 114 & 0,2 & 0,2 & 0,3 \\
\hline Warszawa & 583 & 883 & 92 & 0,2 & 0,1 & 0,3 \\
\hline Szczecin & 463 & 702 & 73 & 0,1 & 0,1 & 0,2 \\
\hline
\end{tabular}

Dla przypadku okresowego działania ogrzewania obliczono również zapotrzebowanie na energię użytkową $\mathrm{Q}_{\mathrm{H}, \mathrm{C}}$, przy założeniu ocieplenia tylko sklepienia. Wyniki kształtują się następująco: Przemyśl 2097 kWh/rok, Białystok 2160 kWh/rok, Wrocław $2059 \mathrm{kWh} /$ rok, Warszawa $1599 \mathrm{kWh} /$ rok, Szczecin 1324 kWh/rok.

Na podstawie otrzymanych wyników obliczeń można stwierdzić, że wykonując ocieplenie sklepienia i montując dodatkowe szklenie osłonowe okien w kościele ogrzewanym stale do temperatury $8^{\circ} \mathrm{C}$ i znajdującym się w okolicach Przemyśla uzyskamy zmniejszenie rocznego zapotrzebowania na energię użytkową $\mathrm{Q}_{\mathrm{H}}$, a tym samym zużycia węgla lub gazu i związaną z tym emisję $\mathrm{CO}_{2}$ o ok. $42 \%$. W pozostałych miastach uzyskano podobne wartości.

W przypadku kościoła ogrzewanego okresowo do temperatury $8^{\circ} \mathrm{C}$ i znajdującego się w okolicach Przemyśla, ilość energii użytkowej $\mathrm{Q}_{\mathrm{H}, \mathrm{C}}$ potrzebnej do pokrycia strat ciepła tylko przez sklepienie zmniejszy się o $63 \%$, a po ociepleniu sklepienia i zamontowaniu dodatkowego szklenia osłonowego zmniejszy się o $87 \%$.

\section{Uwagi końcowe}

W artykule zaprezentowano efekty energetyczne i możliwości wykonania termomodernizacji bryły zabytkowego, murowanego kościoła. Analizie poddano kościół znajdujący się w gminie Zarszyn. Przeprowadzone obliczenia rocznego zapotrzebowania na energię użytkową i końcową dla celów grzewczych kościoła z ciągłym ogrzewaniem (tabela 1 i 2 ) oraz dla kościoła z okresowym ogrzewa- 
niem (tabela 3 i 4) wykazują, że po wykonaniu ocieplenia sklepienia nad nawą i prezbiterium oraz modernizując okna poprzez wykonanie remontu witraży i montaż dodatkowego szklenia osłonowego, można spodziewać się znacznego zmniejszenia zużycia energii na cele grzewcze, a tym samym obniżenia zużycia paliwa np. gazu lub węgla i emisji $\mathrm{CO}_{2}$ do atmosfery.

\section{Literatura}

[1] Piotrowska-Woroniak J., Woroniak G.: Termomodernizacja zabytkowych kościołów, Budownictwo i inżynieria środowiska, nr 5, 2014, s.23-29.

[2] Kurtz-Orecka K., Cierzniewski P.: Problematyka termomodernizacji w budynkach zabytkowych i dawnych, Czasopismo Inżynierii Lądowej, Środowiska i Architektury - Journal Of Civil Engineering, Environment And Architecture, JCEEA, t. XXXII, z. 62 (2/15), kwiecień-czerwiec 2015, s. 249-258, DOI:10.7862/rb.2015.54.

[3] www.zarszyn.pl \{dostęp 12.04.2016 r.\}.

[4] Rozporządzenie Ministra Infrastruktury z dn. 27 lutego 2015r. w sprawie metodologii wyznaczania charakterystyki energetycznej budynku lub części budynku oraz świadectw charakterystyki energetycznej, Dz.U. z 2015, poz.376.

[5] Recknagel H, Sprenger E.: Ogrzewnictwo, klimatyzacja, ciepła woda, chłodnictwo, Wydawnictwo OMNI SCALA, Wrocław 2008.

\section{THE EFFECTS AND POSSIBILITIES OF THERMOMODERNISATION OF A HISTORICAL, STONE CHURCH}

\section{S u m m a r y}

The article presents the extent to which the execution of works permitted by the conservator and associated with insulation of the historical, stone church will reduce the consumption of annual energy for heating purposes and will reduce the occurrence in the church of different unfavourable phenomena associated with heat and ventilation. It was also analysed how much the consumption of fuel for heating (gas and coal) may be reduced and thus the reducing $\mathrm{CO}_{2}$ to the atmosphere. The effects of such thermomodernisation have been compared, with constant and periodic method of heating of the church and for different church locations, in different Polish cities, towns. For analytical purposes a solid of the historical church located in the Zarszyn borough was adopted.

Keywords: usable energy, heating, curtain glazing, $\mathrm{CO}_{2}$ emissions

Przestano do redakcji: 23.05.2016 r.

Przyjęto do druku: 31.03 .2017 r. 